\title{
Pengaruh Komunikasi Organisasi Terhadap Kinerja dan Produktivitas Dosen IPDN
}

\author{
Rinny Dewi Anggraeni, Uliana Ria Sembiring \\ Email : rinny.anggraeni@yahoo.co.id
}

\begin{abstract}
ABSTRAK
Komunikasi merupakan alat penting bagi suatu organisasi, karena komunikasi merupakan alat utama bagi anggota organisasi untuk dapat bekerja sama dalam melakukan aktivitas manajemen, yaitu untuk mencapai tujuan organisasi yang telah ditetapkan sebelumnya. Sumber daya manusia merupakan salah satu sumber daya yang terpenting, manusia sebagai tenga kerja mempunyai peranan yang sangat menentukan terhadap keberhasilan untuk mencapai tujuan organisasi. Komunikasi-komunikasi yang terjadi dalam organisasi berpengaruh pada kepuasan kerja karyawan yang terlibat dalam organisasi tersebut. Komunikasi merupakan dasar bagi semua usaha perubahan yang akan dilakukan organisasi khususnya dalam hal perubahan perbaikan mutu dan mutu ini hanya dapat dicapai jika efektivitas dan efisiensi pengelolaan organisasi berlangsung baik

Penelitian ini bertujuan untuk mengetahui perkembangan perguruan tinggi di Indonesia saat ini yang semakin dituntut untuk meningkatkan kualitasnya, salah satu isu yang menarik adalah masih rendahnya efektivitas organisasi Perguruan Tinggi Negeri (PTN) khususnya pada Perguruan Tinggi Kedinasan (PTK). Produktivitas SDM Indonesia selama ini dinilai termasuk paling rendah jika dibandingkan dengan negara-negara Asia Pasifik.

Data dari penelitian ini diperoleh dengan menggunakan kuesioner dan studi dokumen yang dirumuskan dalam rating scale yang berupa angka kemudian ditafsirkan dalam bentuk kualitatif. Dengan dilakukan dua metode pengujian yaitu, pengujian model keseluruhan (Overal model), pengujian model struktural (Hipotesis Penelitian). Hasil penelitian menjelaskan bahwa pesan komunikasi, media komunikasi, saluran komunikasi, dan aliran komunikasi berpengaruh langsung, positif, dan signifikan terhadap kinerja dosen dan produktivitas dosen dalam pelaksanaan tridharma perguruan tinggi di IPDN.
\end{abstract}

Keyword: Komunikasi Organisasi, Dosen, Produktivitas. 
A. Latar Belakang Masalah

Dalam Undang-undang

Republik Indonesia Nomor 20 Tahun 2003 tentang Sistem Pendidikan Nasional pasal 3, dinyatakan bahwa: Pendidikan Nasional bertujuan untuk berkembangnya potensi peserta didik agar menjadi manusia yang beriman dan bertakwa kepada Tuhan Yang Maha Esa, berakhlak mulia, sehat, berilmu, cakap, kreatif, mandiri, dan menjadi warga negara yang demokratis serta bertanggung jawab. Jadi, dapat disimpulkan bahwa tujuan pendidikan adalah mengembangkan potensi peserta didik agar kelak dapat menjadi manusia Indonesia yang berpegang pada nilai-nilai luhur dan memiliki daya saing yang kuat. Mengenai pendidikan tinggi secara khusus diatur dalam PP 60 tahun 1999 pasal 2 yang bertujuan: a) menyiapkan peserta didik menjadi anggota masyarakat yang memiliki kemampuan akademik dan/atau profesional yang dapat menerapkan, mengembangkan dan/atau memperkaya khasanah ilmu pengetahuan, teknologi dan/atau kesenian; b) mengembangkan dan menyebarluaskan ilmu pengetahuan, teknologi, dan/atau kesenian serta mengupayakan penggunaannya untuk meningkatkan taraf kehidupan masyarakat dan memperkaya kebudayaan nasional.

Tuntutan normatif yang begitu tinggi terhadap pendidikan tinggi di atas, menunjukkan betapa pentingnya misi pendidikan tinggi. Misinya sebagai subsistem pendidikan nasional, untuk mengembangkan kepribadian manusia melalui pengembangan kekuatan penalaran individu, sehingga lulusannya memiliki keunggulan kompetitif. Walaupun demikian, dalam kenyataannya kondisi perguruan tinggi di Indonesia masih jauh dari harapan. Pada sisi lain, kualitasnya secara umum masih rendah.

Keadaan ini sangat membahayakan posisi Indonesia dalam perkembangan iptek yang dapat mempengaruhi perkembangan ekonomi dunia karena ketergantungannya pada tenaga ahli dari luar negeri (Nathan Keyfitz dan Mayling Oey-Gardiner, 1996). Hal ini pula berimplikasi pada rendahnya daya saing tenaga kerja Indonesia dalam memperebutkan kesempatan kerja di era global.

Sehubungan dengan hal tersebut, dipandang mendesak untuk melakukan pembenahan terhadap perguruan tinggi di Indonesia. Untuk maksud itu diperlukan data tentang faktorfaktor yang mempengaruhi kualitas perguruan tinggi, baik yang bersifat internal maupun eksternal. Faktor-faktor eksternal merupakan kekuatan-kekuatan yang tidak dapat dikendalikan oleh pimpinan perguruan tinggi, berbeda dengan faktor-faktor internal. Oleh karena itu, pengkajian atas sumber daya internal serta aspek perilaku organisasi lebih dimungkinkan untuk dilaksanakan.

Di antara sumber daya yang menopang penyelenggaraan perguruan tinggi, sumber daya 
Jurnal LINIMASA, Volume 1 Nomor 2, Juli 2018, hlm 68 - 88

manusia merupakan aset paling penting dan sangat menentukan keberhasilan peran perguruan tinggi. Salah satu sumber daya manusia ini adalah tenaga pengajar (dosen) yang tampil sebagai ujung tombak keberhasilan perguruan tinggi (Lehrer dalam Djatmiko, 2000:2). Oleh karena peranannya yang sangat penting, tenaga pengajar pada perguruan tinggi merupakan sumber daya yang mahal, investasinya lama, dan sangat rentan terhadap gangguan internal maupun eksternal. Mereka mudah mengalami kerusakan, baik karena keusangan ilmu pengetahuan maupun karena gangguan terhadap motivasi sehingga akan mempengaruhi kinerja dan produktivitasnya. Motivasi sebagai salah satu elemen penting dalam perilaku organisasi dan sangat dibutuhkan oleh setiap individu dalam organisasi. Dosen dan karyawan di perguruan tinggi memerlukan dorongan agar mereka merasa bahwa pekerjaan yang mereka tekuni merupakan sesuatu yang besar manfaatnya bagi diri dan orang lain. Dosen tanpa kinerja dan produktivitas yang baik, efektivitas organisasi tidak akan optimal.

Mengamati perkembangan perguruan tinggi di Indonesia saat ini yang semakin dituntut untuk meningkatkan kualitas, namun lemah dalam organisasi. Salah satu isu yang menarik adalah masih rendahnya efektivitas organisasi Perguruan Tinggi Negeri (PTN) khususnya pada Perguruan Tinggi Kedinasan (PTK). Pertanyaannya, mengapa ada sejumlah PTN yang tumbuh dan berkembang dengan baik, sementara sejumlah PTN yang lainnya mengalami stagnasi? Adakah faktor-faktor dominan yang dapat meningkatkan efektivitas sejumlah PTN tersebut sehingga mengalami kemajuan yang cukup berarti dalam mempertahankan kelangsungan hidupnya (survive)? Perguruan Tinggi Kedinasan (PTK) merupakan jenjang pendidikan tinggi yang diselenggarakan untuk menyiapkan mahasiswa aparatur pemerintah menjadi lulusan yang bermutu dan memiliki kemampuan akademik dan atau profesional yang dapat menerapkan, mengembangkan dan menciptakan ilmu pengetahuan serta teknologi di bidangnya. Oleh karena itu, Undang-Undang Nomor 20 Tahun 2003 sebagai pengganti UU Nomor 2 Tahun 1989 tentang Sistem Pendidikan Nasional mencantumkan pendidikan kedinasan pada Pasal 29 ayat (1) yang berbunyi serbagai berikut:

$\begin{array}{lr}\begin{array}{lr}\text { Pendidikan } \\ \text { merupakan }\end{array} & \text { kedinasan } \\ \text { profesi } & \text { yang } \\ \text { diselenggarakan } & \text { oleh } \\ \text { departemen atau lembaga } & \\ \text { pemerintah } & \\ \text { nondepartemen. } \\ \begin{array}{lr}\text { Dijelaskan pula } \\ \text { pendidikan bahwa } \\ \text { merupakan pendidikan } \\ \text { tinggi, sekolah } & \text { program } \\ \text { sarjana } & \text { yang } \\ \text { mempersiapkan } & \text { peserta } \\ \text { didik untuk } & \text { memiliki } \\ \text { pekerjaan } & \text { dengan } \\ \text { persyaratan } & \text { keahlian } \\ \text { khusus (penjelasan pasal }\end{array}\end{array}$


15 ayat 2 UU Sisdiknas

Nomor 20 Tahun 2003).

Pendidikan kedinasan

berfungsi meningkatkan

kemampuan dan

keterampilan dalam

pelaksanaan tugas

kedinasan bagi pegawai

dan calon pegawai negeri

suatu departemen atau lembaga pemerintah nondepartemen. (pasal 29 ayat 2 UU Sisdiknas Nomor 20 Tahun 2003)

Dalam rangka mencapai tujuan seperti telah diuraikan di atas, PTK haruslah berpedoman kepada: tujuan pendidikan nasional, kaidah moral dan etika ilmu pengetahuan, kepentingan masyarakat, serta memperhatikan minat, kemampuan dan prakarsa pribadi. PTK sebagai salah satu satuan pendidikan tinggi menyelenggarakan pendidikan tinggi dan penelitian serta pengabdian pada masyarakat. Penelitian merupakan model atau informasi baru yang memperkaya ilmu pengetahuan, teknologi dan atau kesenian; kemudian pengabdian pada masyarakat merupakan kegiatan yang memanfaatkan ilmu pengetahuan dalam upaya memberikan sumbangan demi kemajuan masyarakat. Ketiga misi dari PTK seperti yang diuraikan di atas disebut dengan tri dharma perguruan tinggi.

Berikut peneliti sajikan data Dosen IPDN tahun 2011 yang menjadi bagian penting dari latar belakang masalah penelitian ini.
Keadaan Responden

Berdasarkan Pengalaman Menjadi Dosen

\begin{tabular}{|c|c|c|c||}
\hline Nomo & Pengalaman \\
$\mathbf{r}$ & $\begin{array}{c}\text { menjadi } \\
\text { Dosen }\end{array}$ & $\mathrm{F}$ & IPDN \\
\cline { 3 - 4 } & $<$ & \\
\hline 1 & $<10$ tahun & 8 & 13,79 \\
\hline 2 & $\begin{array}{c}10-19 \\
\text { tahun }\end{array}$ & $\begin{array}{c}4 \\
2\end{array}$ & 84,48 \\
\hline 3 & $\geq 20$ tahun & 1 & 1,724 \\
\hline \multicolumn{2}{|c|}{ Jumlah } & 5 & 100 \\
\hline
\end{tabular}

Keadaan Responden

Berdasarkan Status Dosen

\begin{tabular}{|c|c|c|c|}
\hline \multirow{2}{*}{$\begin{array}{l}\mathrm{N} \\
\mathrm{o} \\
\mathrm{m} \\
\text { or }\end{array}$} & \multirow[b]{2}{*}{ Status } & \multicolumn{2}{|c|}{ IPDN } \\
\hline & & $\mathrm{f}$ & $\%$ \\
\hline 1 & $\begin{array}{l}\text { Dosen } \\
\text { Tetap }\end{array}$ & 54 & 93,1 \\
\hline 2 & $\begin{array}{l}\text { Dosen } \\
\text { Tidak } \\
\text { Tetap }\end{array}$ & 4 & 6,897 \\
\hline & & 58 & 100 \\
\hline
\end{tabular}

Responden

Berdasarkan

Pendidikan

Terakhir

\begin{tabular}{|c|c|c|c|}
\hline \multirow[t]{2}{*}{ Nomo } & \multirow{2}{*}{ Pendidikan } & \multicolumn{2}{|c|}{ IPDN } \\
\hline & & $\mathrm{f}$ & $\%$ \\
\hline 1 & Sarjana (S1) & 7 & 12,07 \\
\hline 2 & Magister (S2) & 46 & 79,31 \\
\hline 3 & Doktor (S3) & 5 & 8,621 \\
\hline & Jumlah & 58 & 100 \\
\hline
\end{tabular}

Beberapa data empirik menunjukkan informasi bahwa produktivitas SDM Indonesia selama ini dinilai termasuk paling rendah jika dibandingkan dengan negara-negara Asia Pasifik. Sekalipun belum ada data pasti tentang kualitas SDM Indonesia 
Jurnal LINIMASA, Volume 1 Nomor 2, Juli 2018, hlm 68 - 88

namun sudah banyak ahli yang mengungkapkan gambaran kualitas SDM Indonesia dari hasil penelitian mereka. Kompas 20 Oktober 2004 mengungkapkan Human Development Index (HDI) Indonesia berada pada urutan ke112 , di bawah negara yang baru saja bangkit dari perang saudara yang panjang, Vietnam. Fakta ini tentu mengejutkan banyak kalangan dan menuding bahwa pendidikanlah sebagai pokok penyebabnya.

Data yang diungkapkan di atas sekaligus menggambarkan rendahnya produktivitas SDM yang dapat berimplikasi pada laju pertumbuhan ekonomi pada tingkat makro, sedangkan pada tingkat mikro menimbulkan inefisiensi dan inefektivitas. Pada level organisasi hal ini akan berdampak pada rendahnya daya saing dan pada gilirannya akan berpengaruh pada perkembangan secara berkesinambungan (self sustained growth). Dalam konteks perguruan tinggi, seperti IPDN, akan menimbulkan citra yang kurang menguntungkan bagi perkembangannya karena masyarakat akan menjadikannya sebagai pilihan terakhir jika melanjutkan studi sehingga mempengaruhi kualitas calon mahasiswa (praja) dan kelangsungan hidupnya (survival).

Mengingat pentingnya peranan SDM (dosen) pada perguruan tinggi khususnya dalam era global saat ini seiring perkembangan iptek dan sistem informasi yang begitu pesat, maka IPDN harus lebih antisipatif mengembangkan sumber daya dosen sebagai kekuatan utama. Sejalan dengan itu perlu juga memelihara aspek perilaku organisasi dengan baik termasuk komunikasi organisasinya. Dalam kaitannya dengan komunikasi organisasi, apakah dosen di IPDN sudah merasakan bahwa komunikasi yang baik dapat menunjang efektivitas organisasi? Untuk menjawab pertanyaan tersebut sangat sulit mendapat jawaban yang tepat, tetapi dapat dipahami bahwa kepuasan adalah suatu konsep yang biasanya berkenaan dengan kenyamanan. Jadi, kepuasan dalam komunikasi berarti komunikan merasa nyaman dengan pesan-pesan, media yang digunakan, dan hubungan-hubungan dalam organisasi (Pace dan Faules, 2005: 165). Jika melihat kondisi di IPDN yang dijadikan objek penelitian diperoleh gambaran bahwa komunikasi organisasi belum optimal dijalankan. Hal ini didukung oleh data observasi dan wawancara dengan sejumlah dosen yang mengatakan bahwa ada beberapa kebijakan yang tidak disebarluaskan, visi dan misi tidak disosialisasikan, usulan kenaikan pangkat yang tidak jelas mekanismenya, dan pemberitahuan setiap pertemuan kadang kala lambat diinformasikan. Selain itu, ada sebagian pimpinan yang tidak paham kompetensi yang harus dimiliki oleh lulusan IPDN. Data mengenai adanya hambatan komunikasi organisasi ini kemungkinan besar yang mempengaruhi kinerja dan produktivitas yang telah diungkapkan Sebelumnya. Hal ini sebagai gambaran bahwa kinerja 
Nur Arini Shofiya Asu'ari Prodi ilmu Komunikasi...73

dan produktivitas dosen masih rendah yang dapat dijadikan indikator efektivitas dan kemungkinan disebabkan oleh belum terlaksananya komunikasi yang baik antarsesama dosen dan antara dosen dengan pimpinan di IPDN atau unit kerja.

Gambaran tersebut di atas mengindikasikan bahwa komunikasi organisasi, kinerja, dan produktivitas kerja merupakan faktor strategis yang perlu dijaga dan dikembangkan sebagai interface dalam perilaku organisasi. Karena aspek tersebut dipandang strategis dalam mempengaruhi efektivitas organisasi, maka yang harus dilakukan adalah mengupayakan agar ketiganya dapat ditumbuhkembangkan sehingga IPDN mencapai efektivitas yang diharapkan. Hal ini sesuai dengan apa yang dikemukakan oleh Pace dan Faules (1994: 58) bahwa: to study organization is to study organizing behavior, and the heart of behavior is communication. Selanjutnya ia katakan bahwa untuk mengetahui apa yang dipikirkan organisasi, penting sekali memeriksa perilaku-perilaku yang bertautan di antara para anggota organisasi tersebut.

\section{B. Identifikasi dan Rumusan Masalah}

Melalui pernyataan masalah di atas, peneliti membuat identifikasi masalah penelitian sebagai berikut: Proses komunikasi organisasi dengan sejumlah variabel seperti pesan komunikasi, media komunikasi, saluran komunikasi, dan aliran komunikasi di lingkungan IPDN belum berjalan efektif sehingga berpengaruh terhadap kinerja dan produktivitas dosen.

Sehubungan dengan rumusan masalah penelitian di atas, pertanyaan penelitiannya dapat dirumuskan sebagai berikut:

1. Apakah proses komunikasi organisasi yang tercermin dalam bentuk penggunaan pesan komunikasi, media komunikasi, saluran komunikasi, dan aliran komunikasi di lingkungan IPDN berpengaruh langsung, positif dan signifikan terhadap kinerja dosen dalam pelaksanaan tridharma perguruan tinggi?

2. Apakah proses komunikasi organisasi yang tercermin dalam bentuk penggunaan pesan komunikasi, media komunikasi, saluran komunikasi, dan aliran komunikasi di lingkungan IPDN berpengaruh langsung, positif, dan signifikan terhadap produktivitas dosen dalam pelaksanaan tridharma perguruan tinggi?

3. Apakah kinerja dosen berpengaruh langsung, positif, dan signifikan terhadap produktivitas dosen dalam pelaksanaan tridharma perguruan tinggi?

\section{Tujuan dan Manfaat Penelitian}

Tujuan penelitian ini dapat dijelaskan sebagai berikut:

1. Mengumpulkan informasi tentang kegiatan yang dilakukan oleh dosen 
Jurnal LINIMASA, Volume 1 Nomor 2, Juli 2018, hlm 68 - 88

dalam meningkatkan kinerja dan produktivitasnya.

2. Mengetahui pengaruh media komunikasi, saluran komunikasi, arus komunikasi, dan pesan komunikasi terhadap kinerja dosen IPDN dalam pelaksanaan tridharma perguruan tinggi.

3. Mengetahui pengaruh media komunikasi, saluran komunikasi, arus komunikasi, dan pesan komunikasi terhadap produktivitas dosen IPDN dalam pelaksanaan tridharma perguruan tinggi.

4. Mengetahui pengaruh kinerja terhadap produktivitas dosen IPDN dalam pelaksanaan tridharma perguruan tinggi.

5. Mengetahui faktor-faktor yang paling dominan yang mempengaruhi kinerja dosen IPDN.

6. Mengetahui faktor-faktor yang paling dominan mempengaruhi produktivitas dosen IPDN.

7. Merumuskan model empiris yang menggambarkan hubungan antara variabelpesan komunikasi, media komunikasi, saluran komunikasi, dan aliran komunikasi yang dianggap signifikan mempengaruhi peningkatan kinerja dan produktivitas dosen IPDN dalam pelaksanaan

perguruan tinggi.

Hasil dari penelitian secara teoritis diharapkan dapat bermanfaat bagi pengembangan ilmu pengetahuan di bidang pengembangan sumber daya manusia dan perilaku organisasi, khususnya komunikasi organisasi serta pengayaan terhadap hasil penelitian sebelumnya. Manfaat praktisnya adalah sebagai masukan bagi pimpinan IPDN dalam merumuskan kebijakan yang seharusnya dilakukan dalam proses komunikasi organisasi sehingga mendorong peningkatan kinerja dan produktivitas dosen.

\section{Kerangka Pemikiran}

Pengertian produktivitas pada awalnya dikemukakan oleh seorang ekonom Perancis yang bernama Quesney pada tahun 1776, karena itu, sangatlah wajar apabila pengertian produktivitas ini selalu dikaitkan dengan nilai ekonomis suatu kegiatan. Robins (2003: 28) mengatakan bahwa suatu organisasi dikatakan produktif jika organisasi itu mencapai tujuan-tujuannya dengan mengubah masukan menjadi keluaran dengan biaya yang paling rendah, sedangkan Gibson (1985: 20) mendefinisikan bahwa produktivitas adalah pengukuran seberapa baik sumber daya yang digunakan bersama dalam organisasi untuk menyelesaikan kumpulan hasilhasil. Beberapa pandangan juga mengatakan bahwa produktivitas adalah rasio antara keluaran dan masukan dalam satuan waktu tertentu. Hal ini senada dengan pandangan Whitmore (1979) dalam Rosyidi (1997: 23) yang 
mengatakan bahwa: Produktivity is a measure of the use of the resources of an organization and is usually expressed as a ratio of the output obtained by the use resources to the amount of resources employed.

Produktivitas pegawai atau dosen ditentukan oleh tiga faktor, yaitu yang bersumber dari dalam diri dosen, perguruan tinggi, dan lingkungan. Faktor dari dalam diri dosen misalnya motivasi dosen untuk melakukan pekerjaan secara maksimal. Faktor yang bersumber dari perguruan tinggi adalah kebijakan pimpinan dalam pengembangan dosen dan infrastruktur yang berhubungan dengan kesempatan melaksanakan tridharma perguruan tinggi, pengembangan diri berupa studi lanjut dan kegiatan pengembangan lainnya. Adapun faktor lingkungan salah satunya adalah berupa interaksi antar personal dalam lingkungan perguruan tinggi seperti komunikasi organisasi yang baik, dapat mempengaruhi motivasi dosen dan pada akhirnya akan mempengaruhi kinerja dan produktivitasnya.

Sebagai konsekuensinya, pimpinan harus menentukan dan kemudian menghilangkan faktorfaktor yang dapat menghalangi perilaku termotivasi setiap individu. Dengan kata lain, pimpinan harus mampu mendiagnosis orang dan situasi secara akurat guna menjadikan mereka termotivasi dengan baik. Prosedur kerja yang tidak efisien atau tidak tersedianya fasilitas yang memadai dapat mengurangi usaha optimal pegawai atau dosen yang pada akhirnya tidak mendukung peningkatan produktivitas (Sweeney and McFarlin, 2002: 84). Faktor lain yang diduga kuat dapat mempengaruhi produktivitas tersebut adalah, komunikasi organisasi dan kinerja.

Faktor-faktor

yang

dilukiskan dalam gambar 1.1 sangat bergantung pada variabel yang dibahas dalam penelitian ini. Misalnya, pesan komunikasi terkait dengan ketelitian dalam penulisan dan pengucapan pesan atau ketepatan penyebaran, demikian juga dengan media komunikasi terkait dengan kualitas media yang digunakan dalam penyampaian pesan. Saluran komunikasi terkait langsung dengan aksesibilitas atau aliran komunikasi sangat dipengaruhi oleh beban pesan.

Gambar 1.1

\section{Profil Komunikasi Organisasi}

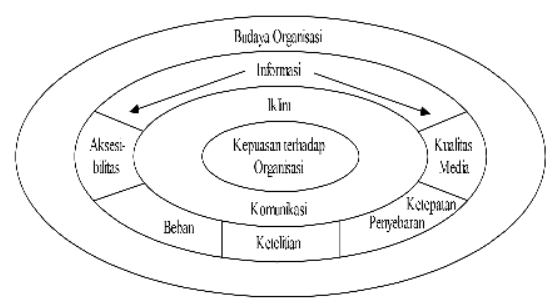

Sumber: Pace dan Faules (2005: 496)

Para dosen perlu mendapatkan informasi tentang tujuan apa saja yang ingin dicapai perguruan tinggi, sumber daya apa saja yang dimiliki perguruan tinggi dalam upaya mencapai tujuan tersebut, mekanisme apa yang dibutuhkan dalam proses pembelajaran, upaya apa yang diperlukan dalam 
Jurnal LINIMASA, Volume 1 Nomor 2, Juli 2018, hlm 68 - 88

mengembangkan diri, dan lain sebagainya.

Semua hal ini penting dikomunikasikan dalam organisasi melalui pesan yang tepat, media yang tepat, saluran yang baik, dan aliran komunikasi yang cepat serta tidak adanya distorsi. Dikatakan oleh Poole (1985) dan Kopelman et al (1989) dalam Suryadi (2004: 30) bahwa hal ini merupakan suasana yang muncul dari dan didukung oleh praktek-praktek yang baik dalam komunikasi organisasi. Suasana baik berkembang dari interaksi antara sifat-sifat suatu organisasi dan persepsi individu atas sifatsifat organisasi. Hal ini merupakan gabungan dari persepsi, perilaku anggota organisasi, respon antar sesama anggota organisasi, harapanharapan, konflik-konflik antar personal, dan kesempatan bagi pertumbuhan dalam organisasi. Suasana atau iklim organisasi mempengaruhi cara hidup anggota organisasi; kepada siapa mereka berbicara, siapa yang mereka sukai, bagaimana perasaan mereka, bagaimana kegiatan kerja mereka, apa yang ingin mereka capai, dan bagaimana cara menyesuaikan diri dengan organisasi. pendidikan dapat ditinjau dari sudut administratif, psikologis, dan ekonomis.

Lebih lanjut Schuler dan Jackson (1997: 119) mengatakan bahwa komunikasi merupakan dasar bagi semua usaha perubahan yang akan dilakukan organisasi khususnya dalam hal perubahan perbaikan mutu dan mutu ini hanya dapat dicapai jika efektivitas dan efisiensi pengelolaan organisasi berlangsung baik. Karena itu, manusia memerlukan komunikasi yang terbuka, tepat, dan dua arah untuk dapat berpartisipasi dalam keberhasilan organisasi. Hal yang hampir sama dikemukakan oleh Sutermesister (1976: 67) yang mengatakan bahwa komunikasi sangat penting dalam mempengaruhi sikap dan motivasi karyawan untuk meningkatkan kinerjanya. Hal itu hanya dapat dilakukan jika pengirim dan penerima pesan memiliki pemahaman yang sama terhadap tujuan komunikasi dan dapat mendorong kestabilan kondisi sosial serta memotivasi anggota organisasi. Ini diartikan oleh Schermerhorn et al (1982: 502) sebagai komunikasi efektif, yang dinyatakan sebagai; "effective communication occurs when the intended meaning of the source and perceived meaning of the receiver are one and the same". Berdasarkan uraian tersebut di atas dapat dirumuskan kerangka konseptual dan paradigma penelitian sebagai berikut:

\section{Paradigma Penelitian}

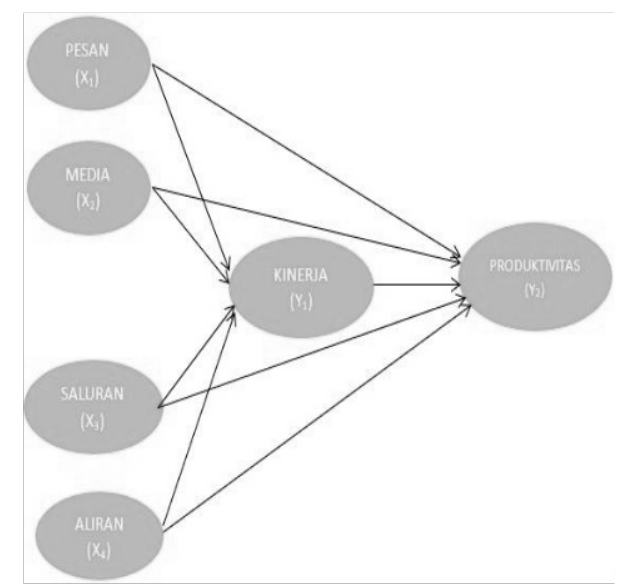


terhadap produktivitas dosen dalam pelaksanaan tridharma perguruan

\section{G. Hipotesis Penelitian}

Berdasarkan

pada rumusan masalah dan tujuan penelitian di atas, maka dapat dirumuskan hipotesis penelitian yang merupakan kesimpulan sementara terhadap masalah yang diteliti. Adapun hipotesis tersebut adalah sebagai berikut:

1. pesan komunikasi, media komunikasi, saluran komunikasi, dan aliran komunikasi berpengaruh langsung, positif, dan signifikan terhadap kinerja dosen dalam pelaksanaan tridharma perguruan tinggi di IPDN;

2. pesan komunikasi, media komunikasi, saluran komunikasi, dan aliran komunikasi berpengaruh langsung, positif, dan signifikan terhadap produktivitas dosen dalam pelaksanaan tridharma perguruan tinggi di IPDN;

3. pesan komunikasi, media komunikasi, saluran komunikasi, dan aliran komunikasi secara simultan berpengaruh positif dan signifikan terhadap kinerja dosen dalam pelaksanaan tridharma perguruan tinggi di IPDN;

4. pesan komunikasi, media komunikasi, saluran komunikasi, dan aliran komunikasi secara simultan berpengaruh positif dan signifikan tinggi di IPDN;

5. kinerja dosen berpengaruh langsung, positif, dan signifikan terhadap produktivitas dosen dalam pelaksanaan tridharma perguruan tinggi di IPDN.

\section{H. Metode Penelitian}

Mengacu pada masalah dan tujuan penelitian, penelitian ini tergolong non eksperimental dan menggunakan pendekatan survei eksplanatori serta Teknik pengumpulan datanya kuisioner dan studi dokumen (Blaxter et al, 1998:59). Dikatakan non eksperimental karena semua variable penerlitian tidak dikendalikan peneliti. Sedangkan metode survei eksplanatori menurut Singarimbun (1987:8) digunakan untuk menjelaskan gejala dan permasalahan dari objek yang diteliti dengan tujuan menjelaskan fenomena yang terjadi dengan cara meneliti hubungan antar variable yang diteliti.

Data yang akan dikumpulkan dengan Teknik survei adalah data variable pesan komunikasi, media komunikasi, saluran komunikasi, aliran komunikasi, dan kinerja dosen, sedangkan data variable produktivitas (produktivitas parsial/individu) dalam hal ini dosen dikumpulkan dengan memakai studi dokumen. Hal ini dilakukan karena menurut Sutermeister produktivitas adalah output yang dihasilkan per jam oleh setiap orang. Artinya, mengukur produktivitas sama 
Jurnal LINIMASA, Volume 1 Nomor 2, Juli 2018, hlm 68 - 88

dengan mengukur hasil yang diperoleh seseorang, bukan proses. Karena itu, tidak tepat jika mengukur produktivitas dengan metode survei karena responden cenderung memperkirakan hasil yang mereka lakukan beberapa waktu yang lalu. Data yang diperoleh dengan cara seperti ini tidak akan akurat.

\section{Teknik Pengumpulan Data}

Data dari penelitian ini diperoleh dengan menggunakan kuesioner dan studi dokumen. Sebagaimana diketahui bahwa kuesioner sebagai alat utama dalam penelitian survei eksplanatori. Cara ini sejalan dengan pandangan Rusidi (1993:16) yang mengatakan bahwa ciri lain dari metode penelitian survei eksplanatori adalah pengumpulan informasi dari sampel atas populasi dengan menggunakan kuesioner sebagai alat pengumpul data. Kuesioner yang dibuat mengacu pada indikator dari semua variabel yang telah dirumuskan dengan menggunakan skala semantic differensial Osgood. Skala ini juga mengukur sikap, pendapat atau persepsi terhadap gejala atau fenomena sosial sama halnya dengan skala ordinal Likert. Skala ini tidak berbentuk pilihan ganda atau checklist tetapi tersusun dalam garis kontinum dengan menempatkan jawaban yang sangat positif (nilai paling besar) di sebelah kanan garis dan jawaban yang sangat negatif (nilai paling kecil) terletak di sebelah kiri garis (Sugiyono, 2000: 78). Selain menggunakan kuesioner untuk beberapa data juga menggunakan studi dokumen untuk ukuran produktivitas dosen dan data identitas pribadi lainnya. Dokumen mengenai ukuran produktivitas dosen dirumuskan dalam rating scale yang berupa angka kemudian ditafsirkan dalam bentuk kualitatif.

\section{Operasionalisasi Variabel Penelitian}

Variabel-variabel dalam penelitian ini, bersumber dari kerangka teoritis yang dijadikan dasar penyusunan konsep berpikir yang menggambarkan secara abstrak suatu gejala sosial. Variabel yang dioperasionalisasikan adalah semua variabel yang terkandung dalam hipotesis penelitian. Cara mengoperasionalisasikan variabel penelitian adalah dengan menjelaskan pengertiannya secara konkret untuk menetapkan aspekaspek dan indikator-indikatornya. Adapun penjelasan setiap variabel adalah sebagai berikut:

a. Pesan komunikasi

Tabel 1.1

Dimensi dan Indikator Pesan Komunikasi

\begin{tabular}{|c|c|c|}
\hline Variabel & $\underset{i}{\text { Dimens }}$ & Indikator \\
\hline \multirow[t]{2}{*}{$\begin{array}{c}\text { Pesan } \\
\text { Komuni } \\
\text { kasi (X1) }\end{array}$} & Clarity & $\begin{array}{l}\text { Scjauhma } \\
\text { na pesan } \\
\text { itu dapat } \\
\text { dipahami } \\
\text { maknanya } \\
\text { oleh } \\
\text { komunika } \\
\text { n } \\
\text { (penerima } \\
\text { pesan) }\end{array}$ \\
\hline & $\begin{array}{l}\Lambda \text { ccura } \\
\text { cy }\end{array}$ & $\begin{array}{l}\text { Sejauhma } \\
\text { na } \\
\text { kebenaran } \\
\text { isi pesan }\end{array}$ \\
\hline
\end{tabular}




\begin{tabular}{|c|c|}
\hline Current & $\begin{array}{l}\text { Keterkini } \\
\text { an atau } \\
\text { kemutakh } \\
\text { iran pesan } \\
\text { (pesan } \\
\text { yang } \\
\text { disampaik } \\
\text { an tidak } \\
\text { out of } \\
\text { date) }\end{array}$ \\
\hline $\begin{array}{l}\text { Credibil } \\
\text { ity }\end{array}$ & $\begin{array}{l}\text { Scjauhma } \\
\text { na pesan } \\
\text { yang } \\
\text { disampaik } \\
\text { an } \\
\text { seseorang } \\
\text { dapat } \\
\text { dipercaya }\end{array}$ \\
\hline $\begin{array}{l}\text { Relevan } \\
\text { cc }\end{array}$ & $\begin{array}{l}\text { Sejauhma } \\
\text { na pcsan } \\
\text { yang } \\
\text { disampaik } \\
\text { an } \\
\text { berkaitan } \\
\text { langsung } \\
\text { dengan } \\
\text { subjck }\end{array}$ \\
\hline
\end{tabular}

c. Saluran Komunikasi

Tabel 1.3

Dimensi dan Indikator Saluran

\begin{tabular}{|c|c|c|c|}
\hline \multicolumn{4}{|c|}{ Komunikasi } \\
\hline $\begin{array}{c}\text { Variab } \\
\mathrm{cl}\end{array}$ & $\begin{array}{c}\text { Dimen } \\
\text { si }\end{array}$ & & dikator \\
\hline $\begin{array}{c}\text { Salura } \\
\text { n } \\
\text { Komu } \\
\text { nikasi } \\
\text { (X3) }\end{array}$ & $\begin{array}{c}\Lambda \text { tas - } \\
\text { Bawah } \\
\text { (Pimpi } \\
\text { nan- } \\
\text { Dosen) }\end{array}$ & 2) & $\begin{array}{l}\text { Informa } \\
\text { si } \\
\text { mengena } \\
\mathrm{i} \\
\text { mengapa } \\
\text { dan } \\
\text { bagaima } \\
\text { na } \\
\text { mclakuk } \\
\text { an suatu } \\
\text { pekerjaa } \\
\mathrm{n} \\
\text { Informa } \\
\text { si } \\
\text { mengena } \\
\mathrm{i} \\
\text { kcbijaka } \\
\mathrm{n} \quad \text { dan } \\
\text { praktek- } \\
\text { praktek } \\
\text { organisa } \\
\text { si } \\
\text { Informa } \\
\text { si } \\
\text { mengena } \\
\mathrm{i} \text { kinerja } \\
\text { dosen } \\
\text { Informa } \\
\text { si untuk } \\
\text { mengem } \\
\text { bangkan } \\
\text { rasa } \\
\text { memiliki } \\
\text { tugas } \\
\text { (sense of } \\
\text { mission }\end{array}$ \\
\hline
\end{tabular}

b. Mcdia Komunikasi

Tabel 1.2

Dimensi dan Indikator Media

Komunikasi

\begin{tabular}{|c|c|c|c|}
\hline Variabel & Dime & \multicolumn{2}{|c|}{ Indikator } \\
\hline \multirow[t]{3}{*}{$\begin{array}{c}\text { Media } \\
\text { Komuni } \\
\text { kasi } \\
\text { (X2) }\end{array}$} & Lisan & $\begin{array}{l}\text { 1) } \\
\text { 2) } \\
\text { 3) }\end{array}$ & $\begin{array}{l}\text { Tatap } \\
\text { muka } \\
\text { l'clcpon } \\
\text { Telekon } \\
\text { ferensi }\end{array}$ \\
\hline & $\begin{array}{l}\text { Tertu } \\
\text { lis }\end{array}$ & $\begin{array}{l}\text { 1) } \\
\text { 2) }\end{array}$ & $\begin{array}{l}\text { Mcmo } \\
\text { Laporan } \\
\text { tertulis } \\
\text { Pcncrbit } \\
\text { an } \\
\text { Papan } \\
\text { pcngum } \\
\text { uman } \\
\text { Pamflet }\end{array}$ \\
\hline & $\begin{array}{c}\text { Gam } \\
\text { bar }\end{array}$ & $\begin{array}{l}\text { 1) } \\
\text { 2) } \\
\text { 3) }\end{array}$ & $\begin{array}{l}\text { Grafik } \\
\text { Poster } \\
\text { Foto }\end{array}$ \\
\hline
\end{tabular}


Jurnal LINIMASA, Volume 1 Nomor 2, Juli 2018, hlm 68 - 88

\begin{tabular}{|c|c|c|}
\hline $\begin{array}{c}\text { Bawah } \\
-\Lambda \text { tas } \\
\text { (Dosen } \\
- \\
\text { Pimpin } \\
\text { an) }\end{array}$ & 3) & $\begin{array}{l}\text { Informa } \\
\text { si tugas } \\
\text { yang } \\
\text { dilakuka } \\
\text { n doscn, } \\
\text { prestasin } \\
\text { ya, } \\
\text { kemajua } \\
\text { nnya, } \\
\text { dan } \\
\text { rencana } \\
\text { dia kc } \\
\text { depan } \\
\text { Informa } \\
\text { si tugas } \\
\text { yang } \\
\text { belum } \\
\text { terpecah } \\
\text { kan dan } \\
\text { bantuan } \\
\text { pemecah } \\
\text { annya } \\
\text { Informa } \\
\text { si saran } \\
\text { pcrbaika } \\
\text { n unit } \\
\text { dan } \\
\text { organisa } \\
\text { si } \\
\text { Informa } \\
\text { si } \\
\text { mengena } \\
\text { i pikiran } \\
\text { dan } \\
\text { perasaan } \\
\text { dosen } \\
\text { tcntang } \\
\text { tugasnya } \\
\text {, rekan } \\
\text { kerja, } \\
\text { dan } \\
\text { organisa } \\
\text { si }\end{array}$ \\
\hline
\end{tabular}

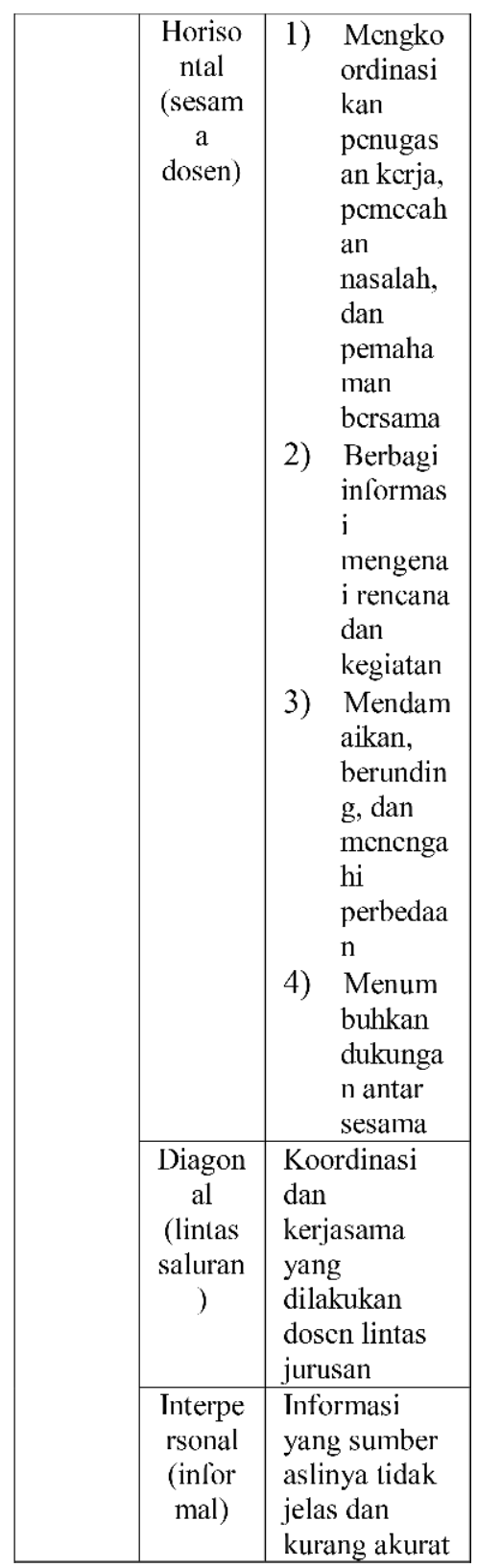


Nur Arini Shofiya Asu'ari Prodi ilmu Komunikasi...81

d. Aliran Komunikasi

Tabel 1.2

Dimensi dan Indikator Media

Komunikasi

\begin{tabular}{|c|c|c|}
\hline Variabel & $\begin{array}{c}\text { Dimen } \\
\text { si }\end{array}$ & Indikator \\
\hline \multirow[t]{3}{*}{$\begin{array}{c}\text { Aliran } \\
\text { Komuni } \\
\text { kasi } \\
\text { (X4) }\end{array}$} & $\begin{array}{c}\text { Kecep } \\
\text { atan }\end{array}$ & $\begin{array}{l}\text { Scjauhmana } \\
\text { pesan } \\
\text { yang } \\
\text { disampaika } \\
\mathrm{n} \\
\text { tiba dengan } \\
\text { cepat }\end{array}$ \\
\hline & $\begin{array}{c}\text { Distors } \\
\mathrm{i}\end{array}$ & $\begin{array}{l}\text { Penyimpan } \\
\text { gan makna } \\
\text { pesan dari } \\
\text { yang } \\
\text { dimaksud } \\
\text { pengirim } \\
\text { dengan } \\
\text { yang } \\
\text { diinterpreta } \\
\text { sikan oleh } \\
\text { pencrima }\end{array}$ \\
\hline & Beban & $\begin{array}{l}\text { Ukuran } \\
\text { mengenai } \\
\text { besar atau } \\
\text { jumlah } \\
\text { informasi } \\
\text { yang } \\
\text { diterima }\end{array}$ \\
\hline
\end{tabular}

e. Produktivitas

\begin{tabular}{|c|c|c|}
\hline $\begin{array}{c}\text { Variab } \\
\text { el }\end{array}$ & Dimensi & Indikator \\
\hline $\begin{array}{c}\text { Aliran } \\
\text { Komu } \\
\text { nikasi } \\
\text { (X4) }\end{array}$ & $\begin{array}{c}\text { Pendidik } \\
\text { an dan } \\
\text { pengajar } \\
\text { an }\end{array}$ & $\begin{array}{l}\text { 1) Jumlah } \\
\text { jam } \\
\text { mengahjar } \\
\text { tiap minggu } \\
\text { 2) Jumlah } \\
\text { jam } \\
\text { membimbin } \\
\text { g di lab dan } \\
\text { bengkel tiap } \\
\text { minggu } \\
\text { 3) Rata-rata } \\
\text { persentase } \\
\text { jumlah } \\
\text { mahasiswa } \\
\text { yang lulus } \\
\text { dari } \\
\text { pelajaran } \\
\text { yang diasuh } \\
\text { 4) } \\
\text { Distribusi } \\
\text { nilai } \\
\text { kelulusan } \\
\text { dari mata } \\
\text { kuliah yang } \\
\text { diasuh }\end{array}$ \\
\hline
\end{tabular}

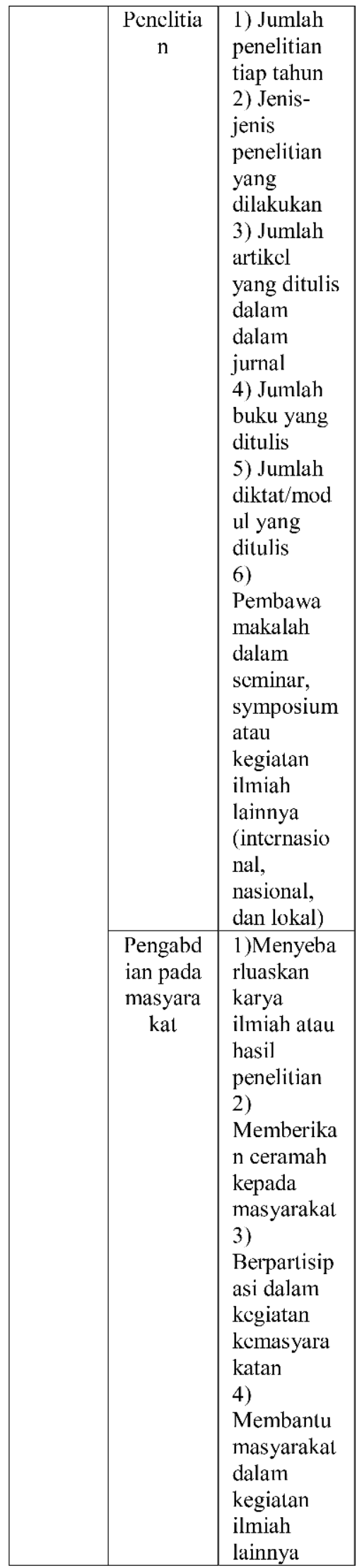


Jurnal LINIMASA, Volume 1 Nomor 2, Juli 2018, hlm 68 - 88

\begin{tabular}{|c|c|}
\hline $\begin{array}{c}\text { Pembim } \\
\text { bingan }\end{array}$ & $\begin{array}{l}\text { 1) Jumlah } \\
\text { mahasiswa } \\
\text { yang } \\
\text { dibimbing } \\
\text { tiap tahun } \\
\text { 2) } \\
\text { Pcrsentase } \\
\text { jumlah } \\
\text { mahasiswa } \\
\text { bimbingan } \\
\text { yang lulus }\end{array}$ \\
\hline $\begin{array}{l}\text { Adminis } \\
\text { trasi } \\
\text { akademi } \\
\quad \mathrm{k}\end{array}$ & $\begin{array}{l}\text { 1) Jumlah } \\
\text { mata kuliah } \\
\text { yang } \\
\text { silabusnya } \\
\text { disusun } \\
\text { 2) } \\
\text { Persentase } \\
\text { kchadiran } \\
\text { mengajar } \\
\text { 3) } \\
\text { Menyerahk } \\
\text { an nilai } \\
\text { tepat waktu }\end{array}$ \\
\hline
\end{tabular}

4. Populasi dan Sampel Penelitian

Penyebaran Populasi dan Sampel untuk Dosen IPDN

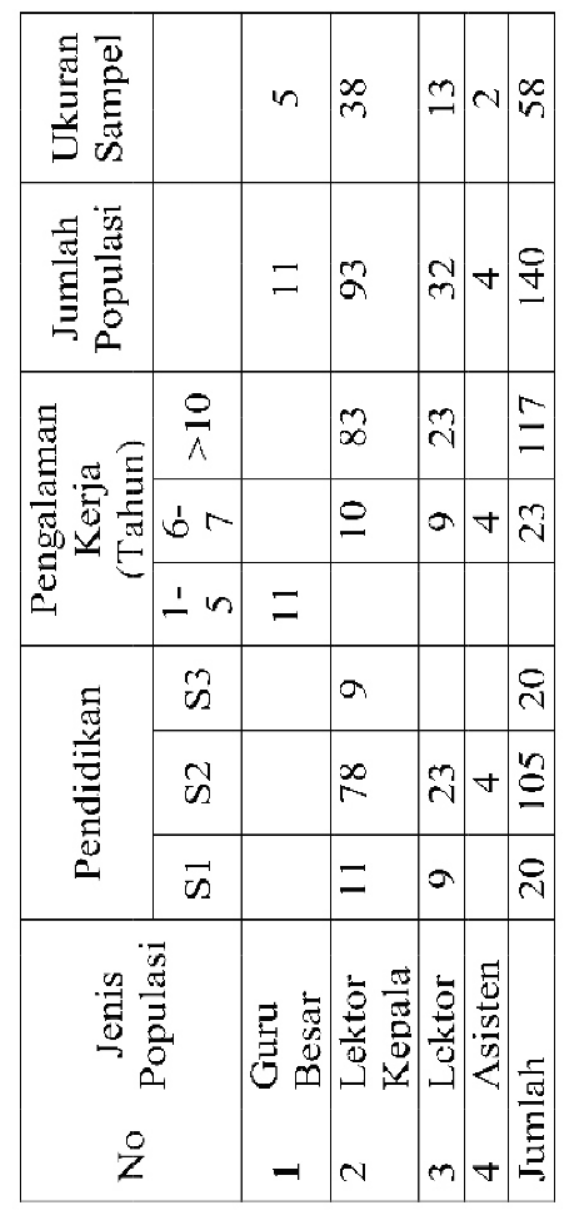

\section{Pengujian Model Keseluruhan (Overal model)}

Model keseluruhan adalah model dalam SEM yang melibatkan beberapa model pengukuran secara terintegrasi. Model keseluruhan ini disusun atau dihubungkan berdasarkan kerangkla konseptual dengan melibatkan model-model pengukuran yang telah diuji sebelumnya, yaitu model pengukuran variabel pesan komunikasi, media komunikasi, saluran komunikasi, aliran 
komunikasi, kinerja dosen, dan produktivitas dosen. Variabel tersebut modelnya fit, instrumennya valid, datanya diasumsikan berdistribusi normal, dan tidak outlier. Model tersebut dievaluasi apakah modelnya sudah fit atau belum. Jika belum fit, maka dilakukan modifikasi indeks untuk mendapatkan model yang fit dan tetap mengacu pada tabel 3.8 untuk menyatakan model tersebut fit atau tidak.

\section{Pengujian Model Struktural (Hipotesis Penelitian)}

Setelah diperoleh model keseluruhan yang fit, maka dilakukan pengujian model struktural. Pengujian ini bertujuan untuk menguji hipotesis sebab akibat antar variabel (Hair et al, 1998:613). Uji statistik yang digunakan adalah uji t yakni didasarkan pada critical value. Signifikansi hubungan tersebut dapat ditentukan berdasarkan nilai Z-Score atau nilai signifikansi yang dalam program LISREL ditunjukkan oleh nilai probabilitas (P). Berdasarkan tabel distribusi $\mathrm{t}$ (Walpole, 1978:514) critical value untuk tingkat ketelitian $10 \%$ adalah 1,645; critical value untuk tingkat ketelitian $5 \%$ adalah 1,96 ; dan critical value untuk tingkat ketelitian $1 \%$ adalah 2,576 (menggunakan dua arah). Untuk penelitian ini digunakan tingkat signifikansi $\quad 5 \% \quad$ sehingga hubungan tersebut dikatakan signifikan jika nilai Z-Score $\geq$ 1,96 atau dengan nilai $\mathrm{P} \geq 0,05$. Berdasarkan hubungan antar variabel yang valid lalu dibuat model struktural dalam bentuk model matematik.

\section{Analisis Pengaruh \\ Langsung (standardized direct effects), Pengaruh tak Langsung (standardized indirect effect), dan Total Pengaruh (standardized total effect)}

Setelah diperoleh hubungan antar variabel yang signifikan dari overall model yang fit, selanjutnya dilakukan analisis pengaruh langsung, pengaruh tidak langsung, dan total pengaruh antar variabel. Pengaruh langsung adalah pengaruh dari suatu variabel secara langsung terhadap variabel lainnya yang tak lain adalah koefisien jalur dari semua garis koefisien dengan anak panah satu ujung. Adapun pengaruh tidak langsung adalah pengaruh yang timbul melalui sebuah intervening variabel (variabel antara) sedangkan total pengaruh adalah penjumlahan dari pengaruh langsung dan pengaruh tidak langsung.

Besarnya pengaruh langsung diperoleh dari nilai standardized regression weight atau standardized direct effect, sedangkan besarnya pengaruh tidak langsung diperoleh dari nilai standardized indirect effect dan besarnya total pengaruh diperoleh dari standardized total effect. Hasil analisis pengaruh tersebut selanjutnya diinterpretasikan dalam kaitannya dengan teori atau hasil penelitian sebelumnya. Reduce Form Structural Equation Modelling

Untuk penyederhanaan penulisan, maka kerangka 
Jurnal LINIMASA, Volume 1 Nomor 2, Juli 2018, hlm 68 - 88

konseptual ditulis seperti gambar 3.2 dengan semua parameternya dan bentuk sederhananya dinyatakan dalam suatu persamaan yang akan diuraikan lebih lanjut.

Gambar 3.2

Koefisien kerangka konseptual

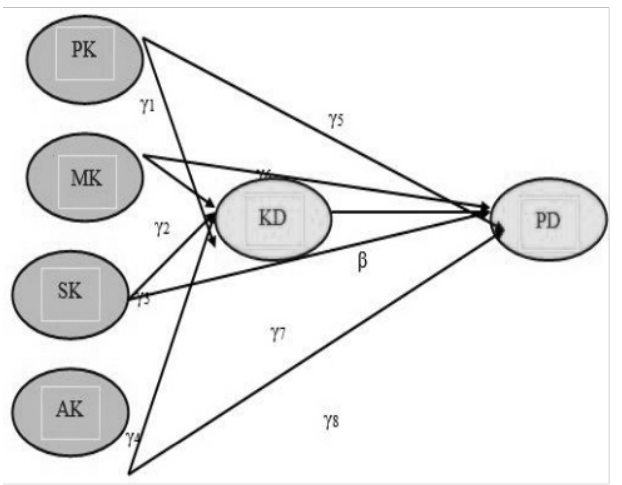

Enam variabel yaitu Pesan Komunikasi (PK), Media Komunikasi (MK), Saluran Komunikasi (SK), Aliran Komunikasi (AK), Kinerja Dosen (KD), dan Produktivitas Dosen (PD) kesemuanya adalah variabel latent atau konstruk yaitu variabel yang tidak dapat diukur secara langsung (unobserved) dan lazim digambarkan dalam elips. Agar variabel tersebut dapat diukur maka perlu dirumuskan suatu variabel yang terukur dan variabel ini disebut dengan variabel manifest dan lazim digambarkan dalam segi empat, (Ghozali, 2004:3). Variabel manifest dalam penelitian ini diberi nama dengan aspek yang telah memiliki sejumlah indikator.
Gambar 3.3

Model Persamaan Struktural

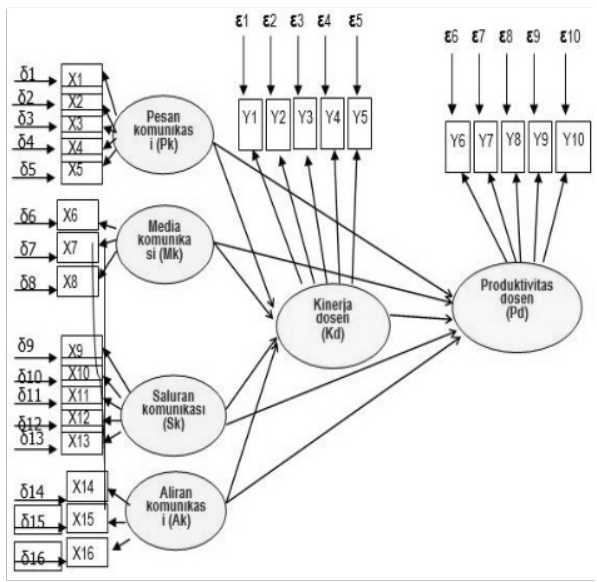

Sebagai contoh variabel latent pesan komunikasi diukur oleh 5 dimensi (indikator) yaitu x1, x2, $\mathrm{x} 3, \mathrm{x} 4$, dan $\mathrm{x} 5$. Dari setiap indikator ini kemudian dirumuskan sejumlah pertanyaan dalam bentuk skala tertentu dengan kesalahan pengukuran (error) masing-masing dengan $\delta 1$, $\delta 2, \delta 3, \delta 4$, dan $\delta 5$ seperti dapat dilihat dalam gambar 3.3.

Persamaan struktural dari gambar 3.3 selanjutnya dinyatakan dalam fungsi linier sebagai berikut:

$$
\begin{gathered}
K D=f(P K, M K, S K, A K) \\
P K=f(P K, M K, S K, A K) \\
\quad(3.1) \\
P D=f(K D)
\end{gathered}
$$

Ketiga fungsi linier ini dapat dibuat model persamaan strukturalnya menjadi

$$
\begin{gathered}
\mathrm{KD}=\mathrm{a}_{1} \mathrm{PK}+\mathrm{a}_{2} \mathrm{MK}+ \\
\mathrm{a}_{3} \mathrm{SK}+\mathrm{a}_{4} \mathrm{AK}+\mathrm{e}_{1} \\
\mathrm{PD}=\mathrm{b}_{1} \mathrm{PK}+\mathrm{b}_{2} \mathrm{MK}+ \\
\mathrm{b}_{3} \mathrm{SK}+\mathrm{b}_{4} \mathrm{AK}+\mathrm{e}_{2} \\
(3.2) \\
\mathrm{PD}=\mathrm{cKD}+\mathrm{e}_{3}
\end{gathered}
$$

ai, bi, dan c adalah koefisien jalur (pengaruh)

ei adalah error (faktor kesalahan) 
Untuk menentukan pengaruh variabel bebas (eksogen) terhadap variabel terikat (endogen) dibuat model matematisnya dengan cara semua variabel endogen dari persamaan (3.2) ditempatkan di ruas kiri dan variabel eksogen di ruas kanan sehingga bentuknya menjadi

$$
\begin{aligned}
& \mathrm{KD} \quad=\mathrm{a}_{1} \mathrm{PK}+ \\
& a_{2} \mathrm{MK}+\mathrm{a}_{3} \mathrm{SK}+\mathrm{a}_{4} \mathrm{AK}+\mathrm{e}_{1} \\
& \mathrm{PK}=\mathrm{b}_{1} \mathrm{PK}+ \\
& \mathrm{b}_{2} \mathrm{MK}+\mathrm{b}_{3} \mathrm{SK}+\mathrm{b}_{4} \mathrm{AK}+\mathrm{e}_{2} \\
& \text { (3.3) } \\
& -\mathrm{cKD} P D=\mathrm{e}_{3} \\
& \begin{array}{llll}
1 & 0 & 0 & \mathrm{KD}
\end{array} \\
& \mathrm{a}_{1} \mathrm{PK}+\mathrm{a}_{2} \mathrm{MK}+ \\
& \mathrm{a}_{3} \mathrm{SK}+\mathrm{a}_{4} \mathrm{AK}+\mathrm{e}_{1} \\
& \begin{array}{llll}
0 & 1 & 0 & \mathrm{PD}
\end{array} \\
& =\quad \mathrm{b}_{1} \mathrm{PK}+\mathrm{b}_{2} \mathrm{MK}+ \\
& \mathrm{b}_{3} \mathrm{SK}+\mathrm{b}_{4} \mathrm{AK}+\mathrm{e}_{2} \\
& \begin{array}{llll}
\text {-c } & 1 & 0 & \mathrm{KD}
\end{array} \\
& \mathrm{e}_{3}
\end{aligned}
$$

Matriks tersebut di atas dapat dinyatakan dengan matriks A Y = $\mathrm{X}$

$$
\begin{aligned}
& \mathrm{Y}=\mathrm{A}^{-1} \mathrm{X} \\
& \mathrm{A}^{-1}=\frac{1}{|A|} \operatorname{adj} A
\end{aligned}
$$

dimana $|A|=\sum_{1}^{3} a_{1 \mathrm{j}}(-1)^{1+\mathrm{j}} \mathrm{M}_{1 \mathrm{j}}=$ $1(-1)^{2} 1=1$

$\operatorname{adj} \mathrm{A}=(\text { kofaktor } \mathrm{A})^{\mathrm{T}}$

\section{J. Kesimpulan dan Saran \\ 1. Kesimpulan}

Proses komunikasi organisasi yang tercermin dalam bentuk penggunaan pesan komunikasi, media komunikasi, saluran komunikasi, dan aliran komunikasi di lingkungan IPDN berpengaruh langsung, positif dan signifikan terhadap kinerja dosen dalam pelaksanaan tridharma perguruan tinggi. Saat ini komunikasi merupakan alat penting bagi suatu organisasi, karena komunikasi merupakan alat utama bagi anggota organisasi untuk dapat bekerja sama dalam melakukan aktivitas manajemen, yaitu untuk mencapai tujuan organisasi yang telah ditetapkan sebelumnya. Sumber daya manusia merupakan salah satu sumber daya yang terpenting, manusia sebagai tenga kerja mempunyai peranan yang sangat menentukan terhadap keberhasilan untuk mencapai tujuan organisasi. Komunikasikomunikasi yang terjadi dalam organisasi berpengaruh pada kepuasan kerja karyawan yang terlibat dalam organisasi tersebut. Komunikasi merupakan dasar bagi semua usaha perubahan yang akan dilakukan organisasi khususnya dalam hal perubahan perbaikan mutu dan mutu ini hanya dapat dicapai jika efektivitas dan efisiensi pengelolaan organisasi berlangsung baik. Proses komunikasi organisasi yang tercermin dalam bentuk penggunaan pesan komunikasi, media komunikasi, saluran komunikasi, dan aliran komunikasi di lingkungan IPDN berpengaruh langsung, positif, dan signifikan terhadap produktivitas dosen dalam pelaksanaan tridharma perguruan tinggi. Kinerja dosen berpengaruh langsung, positif, dan signifikan terhadap produktivitas dosen dalam pelaksanaan tridharma perguruan tinggi? Data yang 
Jurnal LINIMASA, Volume 1 Nomor 2, Juli 2018, hlm 68 - 88

diungkapkan di atas sekaligus menggambarkan rendahnya produktivitas SDM yang dapat berimplikasi pada laju pertumbuhan ekonomi pada tingkat makro, sedangkan pada tingkat mikro menimbulkan inefisiensi dan inefektivitas. Pada level organisasi hal ini akan berdampak pada rendahnya daya saing dan pada gilirannya akan berpengaruh pada perkembangan secara berkesinambungan (self sustained growth). Dalam konteks perguruan tinggi, seperti IPDN, akan menimbulkan citra yang kurang menguntungkan bagi perkembangannya karena masyarakat akan menjadikannya sebagai pilihan terakhir jika melanjutkan studi sehingga mempengaruhi kualitas calon mahasiswa (praja) dan kelangsungan hidupnya (survival).

\section{Saran}

Mengingat pentingnya peranan SDM (dosen) pada perguruan tinggi khususnya dalam era global saat ini dimana iptek dan sistem informasi yang berkembang begitu pesat, maka IPDN harus lebih antisipatif mengembangkan sumber daya dosen sebagai kekuatan utamanya dan memelihara aspek perilaku organisasi dengan baik termasuk komunikasi organisasi.

Dalam kaitannya dengan komunikasi organisasi, komunikasi yang baik dapat menunjang efektivitas organisasi. Untuk menjawab pertanyaan tersebut sangat sulit mendapat jawaban yang tepat, akan tetapi dipahami bahwa kepuasan adalah suatu konsep yang biasanya berkenaan dengan kenyamanan; jadi kepuasan dalam komunikasi berarti komunikan merasa nyaman dengan pesan-pesan, media yang digunakan, dan hubungan-hubungan dalam organisasi.

Jika melihat kondisi di IPDN yang dijadikan objek penelitian diperoleh gambaran bahwa komunikasi organisasi belum optimal dijalankan. Hal ini didukung oleh data observasi dan wawancara dengan sejumlah dosen yang mengatakan bahwa ada beberapa kebijakan yang tidak disebarluaskan, visi dan misi tidak disosialisasikan, usulan kenaikan pangkat yang tidak jelas mekanismenya, pemberitahuan akan setiap pertemuan kadang kala lambat diinformasikan. Selain itu, ada sebagian pimpinan yang tidak paham kompetensi yang harus dimiliki oleh lulusan IPDN. Data mengenai adanya hambatan komunikasi organisasi ini kemungkinan besar yang mempengaruhi kinerja dan produktivitas yang telah diungkapkan di depan. Hal ini sebagai gambaran bahwa kinerja dan produktivitas dosen masih rendah yang dapat dijadikan indikator efektivitas dan kemungkinan disebabkan oleh belum terlaksananya komunikasi yang baik antar sesama dosen dan antara dosen dengan pimpinan di IPDN atau unit kerja. 


\section{DAFTAR PUSTAKA}

Armstrong, $\quad \mathrm{M}$.

Performance

(1994).

London: Kogan Page.

Cartin, T.J. (1999). Principles and

Practices of Organizational

Performance Excellence.

Wisconsin: ASQ.

Devito, J.A. (1997). Komunikasi

Antar Manusia. Jakarta:

Professional Books.

Effendy, O.U. (1993). Human

Relations dan Public Relations.

Bandung: Mandar Maju.

Effendy, O.U. (2004).

Komunikasi: Teori dan Praktek.

Bandung: PT Remaja

Rosdakarya.

Fortunato, R.T. and Waddell,

D.G. (1982). Personal

Administration in Higher

Education. USA: The Jossey-Bass

Gaffar, M.F. (1991). Komunikasi

Organisasi: Teori dan Proses.

Bandung: University Press IKIP

Bandung.

Goldhaber, G.M. (1990).

Organizational Communication.

Dubuque IA: Wm C. Brown

Publishers.

Greenbaum, H.H. et al.(1984).

Organizational Communication.

California: SAGE Publication, Inc.

Hardjana, A. (2000). Audit Komunikasi: Teori dan Praktek. Jakarta: PT Grasindo.

Hellriegel, D. and Slocum Jr, J.W. (2004). Organizational Behavior. Ohio: Thomson.

Kreitner, R. and Kinicki, A. (2003). Perilaku Organisasi. Jakarta: Salemba Empat.

Koehler, J.W., Anatol, K.W.E. and Applbaum,R.L. (1981). Organizational Communication:
Organizational Communication:

Behavioral Perspective.USA:

Holt, Rinehart, and Winston.

Littlejohn, S.W. and Foss, K.A. (2005). Theories of Human Communication. USA: Thomson

Muhammad, A. (2005).

Komunikasi Organisasi. Jakarta:

PT Bumi Aksara.

Mulyana, D. (2004). Komunikasi Efektif: Suatu Pendekatan Lintas Budaya. Bandung: PT Remaja Rosdakarya.

Myers, M.T. and Myers, G.E. (1982). Managing by Communication: An Organizational Approach. New York: McGraw-Hill.

Pace, R.W. and Faules, D.F. (2005). Komunikasi Organisasi. Strategi Meningkatkan Kinerja Perusahaan. Bandung: PT Remaja Rosdakarya.

Robbins, S.P. (2003). Perilaku Organisasi. Jakarta: Indeks.

Rogers, E.M. and Shoemaker, F.F. (1971). Communication of Innovations. New York: Macmillan Publishing Co. Inc.

Schermerhorn, Jr. J.R., Hunt, J.G, and Osborn, R.N. (1985). Managing Organizational Behavior. New York: John Wiley \& Sons.

Sedarmayanti. (2001). Sumber Daya Manusia dan Produktivitas Kerja. Bandung: CV Mandar Maju.

Sendjaya, S.D. (1994). Teori Komunikasi. Jakarta: Universitas Terbuka.

Siagian, S.P. (2002). Kiat Meningkatkan Produktivitas Kerja. Jakarta: Rineka Cipta.

Sinungan, M. (2003). 
Jurnal LINIMASA, Volume 1 Nomor 2, Juli 2018, hlm 68 - 88

$\begin{array}{llrlr}\text { Sinungan, } & \text { M. } & \text { (2003). } & \text { Dalam } & \text { Corporate } \\ \text { Produktivitas: } & \text { Apa } & \text { dan } & \text { Communications: } & \text { An }\end{array}$

Bagaimana. Jakarta: Bumi International Journal. [Online],

Aksara.

Vol. 8 (3), 10 halaman. Tersedia:

Soehendro, B. (1996). Kerangka

Pengembangan Pendidikan

http://www.emeraldinsight.com/re searchregister. [15 Juni 2005].

Tinggi Jangka Panjang 19962005. Jakarta: Ditjen Dikti.

Sweeney, P.D. and McFarlin, D.B. (2002). Organizational Behavior: Solutions for

Management. New. York:

McGraw-Hill.

Sutermeister, R.A. (1976). People and Productivity. New York: McGraw-Hill.

Tan, A.S. (1981). Mass Communication: Theories and Research. Colombus, Ohio: Grid Publishing Inc.

Timpe, $\Lambda . D$. (Eds) (1992). Kinerja. Jakarta: PT Alex Media Computindo.

(Eds)
Produktivitas. Jakarta: Media Computindo.

Tubbs, S.L. and Moss, S. (2000).

Human Communication.

Bandung: PT Remaja

Rosdakarya.

Widjaya, A.W. (1986). Komunikasi dan Hubungan Masyarakat. Jakarta: PT Bina Aksara.

JURNAL DARI INTERNET:

Adams, A. and Blandford, A. (2005). Organisational Communication and Awareness: A Novel Solution for Health Informatics. Dalam Health Informatics Journal. [Online], Vol. 9 (3), 12 halaman.

Tersedia:

http://www.uclic.ucl.ac.uk/annb/d ocs/aaabdbnbIIIJ preprint.pdf. [10 Januari 2006].

Daly, F., Teague, P. and Kitchen P. (2003). Exploring the Role of Internal Communication During Organisational Change.
Elving, W.J.L. (2005). "The Role of Communication in Organisational Change". Corporate Communications: Dalam Corporate Communications: An International Journal. [Online], Vol. 10 (2), 10 halaman.

Tersedia:

http://www.emeraldinsight.com/re searchregister. [10 Januari 2006].

Kelly, D. (2000). "Using Vision to Improve Organisational Communication". Dalam Leadership \& Organization Development Journal. [Online], Vol. 21 (2), 10 halaman. Tersedia: http://www.emerald-library.com. [15 Juni 2005].

Peng, W. and Litteljohn, D. (2001). Organisational Communication and Strategy Implementation a Primary Inquiry. Dalam International Journal of Contemporary Hospitality Management. |Online|, Vol. 13 (7), 4 halaman. Tersedia: http://www.emeraldlibrary.com/ft. [15 Juni 2005].

Tukiainen, T. (2001). "An Agenda Model of Organisational Communication". Dalam Corporate Communications: An International Journal. 「Online $\rceil$, Vol. 6 (1), 6 halaman. Tersedia: http://www.mcbup.com/researchr egisters. [15 Juni 2005].

Molesworth, M. and Knott, J.D. (2004). An Exploratory Study of the Failure of Online Organisational Communication. Dalam Corporate Communication: An International Journal. |Online |, Vol. 9 (4), 15 halaman. Tersedia: http://www.emeraldinsight.com/re searchregister. [10 Januari 2006]. 